\title{
Nanogram per Milliliter per Milligram per Meter Squared
}

National Cancer Institute

\section{Source}

National Cancer Institute. Nanogram per Milliliter per Milligram per Meter Squared. NCI

Thesaurus. Code C119446.

A unit of concentration equal to nanograms per milliliter, divided by milligrams per meter squared. 